\title{
KEMAMPUAN SISWA MEMECAHKAN SOAL SETARA PISA KONTEKS PEKERJAAN : STUDI PENGEMBANGAN SOAL PISA KONTEN CHANGE AND RELATIONSHIP
}

\author{
Ahmad Nasriadi ${ }^{1)}$, Intan Kemala Sari ${ }^{2)}$ \\ ${ }^{1,2)}$ STKIP Bina Bangsa Getsempena, Banda Aceh \\ e-mail: ${ }^{1)}$ ahmad@stkipgetsempena.ac.id; ${ }^{2)}$ intankemalasari00@gmail.com
}

\begin{abstract}
This research developed the equivalent of PISA problems, change and relationship content, and work context, in low order thinking level, consisting of two problems. The purpose of this research is to see the student's response in solving the PISA problems. The results of this study indicate that students feel the problem is quite difficult due to unfamiliar students solve the problems associated with real context that exist in their daily life, but also students must build their own personal concept to solve the problem. The response in this study indicates that students are challenged to solve the problem and feel happy when it can solve it. This confirms that in learning mathematics there needs to be a challenge of problems associated in the daily life of students to build their personal concept in solving problems until students are able to find a formal concept.
\end{abstract}

Keywords : PISA problems, real context, personal concept

\begin{abstract}
Abstrak
Penelitian ini mengembangkan soal setara PISA konten change and relationship, konteks pekerjaan, dalam low order thinking level, yang terdiri dari dua soal.tujuan penelitian ini adalah untuk melihat respon siswa dalam memecahkan masalah setara PISA tersebut. Hasil penelitian ini menunjukkan bahwa siswa merasa soal tersebut cukup sulit yang disebabkan karena tidak terbiasanya siswa memecahkan msalah yang terkait dengan kejadian nyata yang ada dalam kehidupan sehari-harinya, selain itu juga siswa harus membangun sendiri konsep pribadinya untuk memecahkan masalah tersebut. Respon dalam penelitian ini menunjukkan bahwa siswa tertantang untuk memecahkan soal tersebut dan merasa senang ketika dapat menyelesaikannya. Ini mempertegas bahwa dalam belajar matematika perlu adanya tantangan masalah yang dikaitkan dalam kehidupan sehari-hari siswa untuk membangun konsep pribadinya dalam memecahkan masalah hingga siswa mampu menemukan konsep formal.
\end{abstract}

Kata Kunci : Soal PISA, masalah nyata, konsep pribadi

\section{PENDAHULUAN}

Pendidikan merupakan suatu aktivitas penting dalam kehidupan untuk meningkatkan kualitas sumber daya manusia dalam menjamin kelangsungan hidup dan kemajuan suatu bangsa. Peningkatan kualitas SDM merupakan kepentingan yang sangat diperhatikan jauh lebih mendesak untuk segera direalisasikan terutama dalam 
menghadapi persaingan Masyarakat Ekonomi Asean (MEA) dan persaingan global. Oleh karena itu, peningkatan kualitas sumber daya manusia handal yang memiliki pemikiran kritis, sistematis, logis, kreatif, dan kemauan untuk bekerja sama secara efektif sejak dini merupakan hal yang harus dipikirkan dengan sungguh-sungguh. Salah satu upaya peningkatan kualitas sumber daya manusia yang memiliki pemikiran seperti yang telah disebutkan itu dapat dihasilkan dari lembaga pendidikan terutama di sekolah.

PISA (Programme for International Student Assessment) merupakan salah satu program internasional untuk mengukur tingkat keberhasilan pendidikan suatu negara. PISA fokus pada suatu kontes literasi tiga tahunan yang menilai kemampuan anak umur 14-15 tahun dalam menerapkan pengetahuan dan keterampilan yang telah mereka pelajari di sekolah untuk masalah yang sering dihadapi sehari-hari. PISA diselenggarakan sejak tahun 2000 oleh Organisation for Economic Co-operation and Development (OECD) yang diikuti lebih dari 70 negara di dunia termasuk Indonesia. Tjalla (2009: 2) menyebutkan bahwa studi PISA yang dilaksanakan oleh OECD dan Unesco Institute for Statistics itu mengukur kemampuan siswa pada akhir usia wajib belajar untuk mengetahui kesiapan siswa menghadapi tantangan masyarakatberpengetahuan (knowledge society) dewasa ini. Penilaian yang dilakukan dalam PISA berorientasi ke masa depan, yaitu menguji kemampuan anak muda itu untuk menggunakan keterampilan dan pengetahuan mereka dalam menghadapi tantangan kehidupan nyata, tidak semata-mata mengukur kemampuan yang dicantumkan dalam kurikulum sekolah.

Keterlibatan Indonesia dalam PISA adalah salah satu upaya untuk melihat sejauh mana perkembangan program pendidikan di Indonesia dibadingkan dengan negara-negara lain. $\operatorname{OECD}$ (2007, 2010, dan 2013), Tjalla (2009:18), Wardhani (2011:1), dan Putri (2011:2) mengatakan bahwa Indonesia sendiri telah mengikuti PISA sejak tahun 2000, 2003, 2006, dan 2009 dengan hasil tidak menunjukkan banyak perubahan pada setiap keikutsertaannya. Pada survei PISA 2003, pada bidang matematika lebih dari 50 persen siswa dari Indonesia mencapai level terendah dengan skor di bawah 358. Pada survei PISA tahun 2006, peringkat Indonesia untuk matematika turun pada 38 dari 40 negara (2003) menjadi urutan 52 dari 57 negara, dengan skor rata-rata turun dari 411 (2003) menjadi hanya 391 (2006). Kemudian pada PISA 2009 Indonesia hanya menduduki rangking 61 dari 65 peserta dengan rata-rata 
skor 371, sementara rata-rata internasional adalah 496. Dan pada PISA 2012 Indonesia menduduki kedua terbawah dengan perolehan nilai 375 sementara rata-rata international adalah 494 (OECD, 2013).

PISA framework 2012 menjelaskan bahwa kerangka soal PISA matematika mempunyai 3 dimensi, diantaranya : (1) content (isi), (2) context (situasi), dan (3) competency cluster (kelompok kompetensi). Soal PISA dikembangkan berdasarkan 4 konten, keempat konten tersebut meliputi: Shape and Space, Change and Relationship, Quantity, dan Uncertainty and Data. Salah satu dari empat konten soal PISA adalah konten Change and Relationship. Soal-soal PISA pada konten Change and Relationship menyeluruh berfokus pada kebutuhan untuk kuantifikasi. Aspek penting meliputi pemahaman ukuran relatif, pengakuan pola numerik, dan kemampuan untuk menggunakan angka untuk mewakili atribut kuantitatif objek dunia nyata. Pada konten ini juga berkaitan dengan pokok pelajaran aljabar. Hubungan matematika sering dinyatakan dengan persamaan atau hubungan yang bersifat umum, seperti penambahan, pengurangan, dan pembagian. Hubungan itu juga dinyatakan dalam berbagai simbol aljabar, grafik, bentuk geometris, dan tabel. Oleh karena setiap representasi simbol itu memiliki tujuan dan sifatnya masing-masing, proses penerjemahannya sering menjadi sangat penting dan menentukan sesuai dengan situasi dan tugas yang harus dikerjakan.

Berdasarkan pernyataan di atas dapat disimpulkan bahwa Indonesia masih berada di bawah rata-rata dalam kompetisi internasional. Siswa Indonesia masih kurang mampu dalam menyelesaikan masalah matematis dalam kehidupan sehari-hari. Hal ini disebabkan karena belum tersedianya soal-soal yang mengukur kemampuan komunikasi matematis siswa seperti soal-soal non-rutin model PISA. Kebanyakan guru di sekolah masih kurang memahami atau menguasai tentang soal model PISA, sehingga soal-soal yang diberikan kepada siswa hanya soal-soal rutin. Dari hasil survey PISA tersebut dapat dilihat bahwa prestasi anak Indonesia dalam bidang matematika masih berada di bawah skor rata-rata internasional.

Adapun yang menjadi ruang lingkup dalam penelitian ini yaitu mengembangkan soal-soal model PISA (Programme for International Student Assessment) pada konten change and relationship, untuk selanjutnya dilihat berapa besar kemampuan siswa dalam memecahkan masalah tersebut, apa solusi yang terpikirkan oleh siswa, serta letak-letak kesalahan yang muncul. Ini dapat menjadi referensi bagi pengembang mutu 
pendidikan dan pengelola serta pelaksanan proses belajar mengajar agar dapat melihat dengan jeli segala kemungkinan kecil dan belum terpikirkan oleh banyak pihak tentang dimana kelemahan dan kekurangan kita dalam mengajarkan matematika.

Mengingat luasnya lingkup soal PISA, maka dari itu pengembangan soal-soal model PISA sangat diperlukan guna meningkatkan kemampuan siswa dalam menyelesaikan masalah matematis dalam kehidupan sehari-hari. Dengan demikian, Penelitian ini bertujuan untuk mengamati respons siswa yang terhadap mengembangkan soal-soal setara PISA pada konten change and relationship dan konteks pekerjan. Respon yang dimaksud dapat berupa kemampuan memecahkan masalah, strategi yang digunakan untuk menyusun rencana solusi, serta alternatif-alternatif kesalahan yang mungkin muncul selama memecahkan masalah.

PISA mengembangkan enam kategori kemampuan matematika siswa yang menunjukkan kemampuan kognitif dari siswa. Tingkatan kemampuan matematika menurut PISA bahwa penilaian literasi matematis yang dilakukan oleh studi PISA ini terdiri dari 6 tingkatan atau level. Soal literasi matematis level 1 dan 2 termasuk kelompok soal dengan skala bawah yang mengukur kompetensi reproduksi. Soal-soal disusun berdasarkan konteks yang cukup dikenal oleh siswa dengan operasi matematika yang sederhana. Soal literasi matematis level 3 dan 4 termasuk kelompok soal dengan skala menengah yang mengukur kompetensi koneksi. Soal-soal skala menengah memerlukan interpretasi siswa karena situasi yang diberikan tidak dikenal atau bahkan belum pernah dialami oleh siswa. Sedangkan, soal literasi matematis level 5 dan 6 termasuk kelompok soal dengan skala tinggi yang mengukur kompetensi refleksi. Soalsoal ini menuntut penafsiran tingkat tinggi dengan konteks yang sama sekali tidak terduga oleh siswa (Maryanti, 2012). Hal ini juga berarti bahwa level 4-level 6 soal pada PISA tergolong sebagai High Order Thingking berdasarkan taksonomi bloom, sedangkan level 1-3 adalah Low Order Thingking.

Change and relationship (perubahan dan hubungan) berkaitan dengan pokok pelajaran aljabar. Hubungan matematika sering dinyatakan dengan persamaan atau hubungan yang bersifat umum, seperti penambahan, pengurangan, dan pembagian. Hubungan itu juga dinyatakan dalam berbagai simbol aljabar, grafik, bentuk geometris dan tabel. Oleh karena setiap representasi simbol itu memiliki tujuan dan sifatnya 
masing-masing, proses penerjemahannya sering menjadi sangat penting dan menentukan kesesuaian dengan situasi dan tugas yang harus dikerjakan (OECD, 2009a).

Pada penelitian ini, pengembangan soal matematika setara PISA pada materi change and relationship untuk siswa SMP/MTs ini berbentuk soal uraian yang dilakukan dengan tes tertulis berupa pemberian kumpulan soal-soal kepada siswa dalam bentuk tulisan. Soal uraian merupakan suatu soal yang jawabannya menuntut siswa untuk mengingat dan mengorganisasikan gagasan dan pikirannya, mengemukakan pendapat dan mengekspresikan gagasan tersebut dengan menggunakan kalimatnya sendiri. Melalui soal pada bentuk ini peneliti dapat menganalisis bentuk dan strategi jawaban siswa serta mencari tahu tentang bentuk-bentuk kelemahan siswa agar dapat dicarikan alternatif solusi untuk pembelajaran yang akan datang.

\section{METODE PENELITIAN}

Penelitian ini merupakan jenis penelitian pengembangan yaitu suatu proses atau langkah-langkah untuk mengembangkan suatu produk baru, atau menyempurnakan produk yang telah ada, yang dapat dipertanggungjawabkan (Sudjadi, 2003:164). Adapun objek yang dikembangkan yaitu soal-soal setara PISA yang valid, praktis, dan efektif, sehingga dapat dimanfaatkan untuk kalangan luas.

Arikunto (2010:211) menuliskan bahwa: "validitas adalah suatu ukuran yang menunjukkan tingkat-tingkat kevalidan atau kesahihan sesuatu instrumen. Sebuah instrumen dikatakan valid apabila mampu mengukur apa yang diinginkan”. Validitas suatu instrumen penelitian, tidak lain adalah derajat yang menunjukkan suatu tes mengukur apa yang hendak diukur. Validitas suatu tes yang perlu diperhatikan oleh peneliti adalah bahwa ia hanya valid untuk suatu tujuan tertentu saja. Secara metodologis, validitas suatu tes dapat dibedakan menjadi empat macam, yaitu validitas: isi, konstruk, konkuren dan prediksi.

Praktis secara bahasa berarti mudah digunakan. Menurut Nieven (dalam Haviz, 2013) aspek praktis dalam penelitian ini hanya dapat dipenuhi jika para praktisi menyatakan soal yang dikembangkan dapat diterapkan, dan tingkat keterlaksanaan produk termasuk dalam kategori baik, artinya masih memerlukan indikator lanjutan terutama dalam pelaksanaan produk pembelajaran yang telah dikembangkan. Pada 
penelitian ini praktis yang dimaksud adalah soal yang dikembangkan dapat diterapkan oleh guru dalam proses pembelajaran, dan mudah dimengerti oleh peserta didik.

Aspek keefektifan biasanya berkaitan erat dengan perbandingan antara tingkat pencapaian tujuan dengan rencana yang telah disusun sebelumnya. Nieveen dalam Rochmad (2011:17) menyatakan bahwa keterlaksanaan model dikatakan efektif dilihat dari komponen-komponen: (1) hasil belajar siswa, (2) aktivitas siswa dan (3) respon siswa. Hal ini berdasarkan pada tingkatan pengalaman dan hasil intervensi konsisten dengan tujuan yang dimaksud. Tingkatan pengalaman ini dengan adanya respon positif dari siswa yang ditunjukkan melalui angket yang diberikan sedangkan intervensi konsisten dengan tujuan yang dimaksud ditunjukkan dengan tes hasil belajar.

Untuk menguji aspek-aspek tersebut, penelitian ini dilakukan dengan menggunakan formative evaluation yang dikembangkan oleh Tessmer (1993) yang melibatkan enam sekolah berbeda di Banda Aceh dengan total jumlah responden yaitu 136 siswa usia 14-15 tahun. Adapun klasifikasi kategori siwa yang menjadi subjek penelitian ini yaitu siswa dengan kemampuan menengah ke atas dari sekolah dengan reputasi baik dan unggul di Banda Aceh.

Uji coba pengembangan soal tersebut pada kelompok responden yang lebih besar. Ini menjadi soal tes bagi responden sekaligus menjadi analisis bagi peneliti untuk mengetahui strategi-strategi yang digunakan responden dalam menyelesaikan masalah yang diajukan dalam penelitian. Selain memberikan soal dalam bentuk tes, peneliti juga memberikan lembar refleksi bagi responden untuk menuliskan pengalaman dan perasaannya setelah menyelesaikan tes pemecahan masalah dengan soal setara PISA tersebut.

\section{HASIL PENELITIAN DAN PEMBAHASAN}

Penelitian ini telah mengembangkan soal setara PISA pada konteks pekerjaan sebanyak lima soal. Hasil dari pengembangan soal tersebut diujicobakan di sekolah menengah pertama yang ada di Banda Aceh untuk melihat respon siswa terhadap soal tersebut. Adapun hasil pengembangan soal tersebut dijelaskan sebagai berikut : 


\section{Konten Soal : Change and R elationship \\ Fokus Soal : Persamaan L inier Dua Variabel \\ Konteks Soal : Pekerjaan \\ Kompetensi : M engaplikasikan model-model matematika}

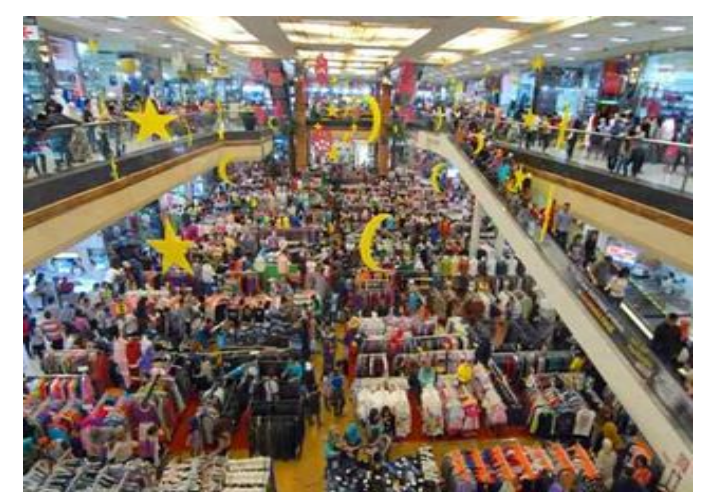

Sebuah pusat perbelanjaan memberlakukan aturan jam kerja pegawai sebagai berikut: setiap pegawai tetap wajib bekerja 8 jam per hari dan maksimal 40 jam per minggu. Sedangkan karyawan yang bekerja lebih dari waktu tersebut akan diberikan honor lembur. Besarnya honor lembur yaitu Rp. 10.000/ 30 menit.

A dapun aturan jam kerja pegawai adalah sebagai berikut:

Jam K erja Pagi : $08.00-13.00$

Jam K erja Siang : $13.00-18.00 \quad$ Istirahat I : $13.00-14.00$

J am K erja M alam : $18.00-22.00 \quad$ Istirahat II : $18.00-19.00$

\section{Soal 1.}

K ahfiadalah salah satu karyawan di pusat perbelanjaan tersebut. J ika K ahfi menginginkan honor lembur Rp. 300.000 per bulan, berapa tambahan jam kerja yang harus $\mathrm{K}$ ahfi capai?

\section{Soal 2.}

Selama dua minggu berturut-turut $\mathrm{K}$ ahfi mendapatkan jam kerja pagi sebanyak 3 kali per minggu, jam kerja siang sebanyak 2 kali, dan jam kerja malam sebanyak 3 kali perminggu. Dengan ketentuan mengambil dua shif per hari untuk mencapai jam kerja wajib 8 jam per hari, Tentukan besar honor lembur K ahfi untuk dua minggu tersebut!

\section{Gambar 1. Hasil pengembangan soal}

Pengembangan soal tersebut memilih konteks pekerjaan yang bisa dibayangkan oleh siswa karena peristiwa tersebut ada dalam kehidupan sehari-harinya. Prinsip pemilihan konteks tersebut sesuai dengan de Lange (dalam Sari, 2016) yaitu bahwa konteks nyata akan dapat membangun konsep matematika siswa dengan model yang 
dibangunnya sendiri. Hal ini menjadi lebih dekat dengan siswa karena kejadian tersebut ada di sekitarnya, selain itu juga memberi makna bahwa matematika merupakan ilmu yang bermanfaat dalam kehidupan nyata. Selain memilih konteks pekerjaan, soal ini juga dirancang dengan memandang nilai-nilai positif, dengan kata lain, tidak ada pembuatan soal dengan mengukur keterlambatan seseorang dalam bekerja, melaikan dengan mempertimbangkan penghargaan yang didapat seseorang atas kerajinannya dalam bekerja. Dengan demikian pembuatan soal ini dirancang untuk memikirkan halhal positif dengan tujuan agar terciptanya pembentukan karakter positif siswa dalam kehidupan sehari-hari secara tidak langsung.

Kedua soal tersebut melibatkan konsep persamaan linier satu variabel yang cukup sederhana, di mana siswa diminta untuk menentukan jam kerja tambahan agar mendapatkan honor lembur yang diinginkan. Sedangkan soal kedua menentukan berapa honor lembur yang didapat jika dia diberikan jam kerja yang telah ditentukan. Kedua soal ini memuat low order thinking level dengan kriteria berikut.

Tabel 1. Tingkat kemampuan matematika siswa berdasarkan PISA Level 1-3

\begin{tabular}{|c|l|}
\hline Level & \multicolumn{1}{c|}{ Deskrip } \\
\hline Level 3 & $\begin{array}{l}\text { Siswa dapat melaksanakan prosedur dengan baik, memilih dan menerapkan } \\
\text { strategi memecahkan masalah yang sederhana, mampu mengiterpretasikan dan } \\
\text { menggunakan representasi berdasarkan sumber informasi yang beredar dan } \\
\text { mengemukakan alasannya, serta mengkomunikasikan hasil interpretasi dan alasan } \\
\text { mereka. }\end{array}$ \\
\hline Level 2 & $\begin{array}{l}\text { Siswa mampu menginterpretasikan dan mengenali situasi dalam konteks yang } \\
\text { memerlukan inferensi langsung, memilih informasi yang relevan dari sumber } \\
\text { tunggal, mengerjakan algoritma dasar, menggunakan rumus, melaksanakan } \\
\text { prosedur atau konvensi sederhana, memberikan alasan secara langsung dan } \\
\text { melakukan penafsiran harfiah. }\end{array}$ \\
\hline Level 1 & $\begin{array}{l}\text { Siswa mampu menjawab pertanyaan yang konteksnya umum dan dikenal serta } \\
\text { semua informasi yang relevan tersedia dengan pertanyaan yang jelas, } \\
\text { mengidentifikasi informasi dan menyelesaikan prosedur rutin menurut instruksi } \\
\text { yang eksplisit, serta melakukan tindakan sesuai dengan stimulasi yang diberikan. }\end{array}$ \\
\hline
\end{tabular}

Sumber : Johar, 2012

Kedua soal tersebut memang belum termasuk dalam kategori High Order Thinking, namun berdasarkan hasil studi lapangan, hal ini bukanlah masalah yang mudah dipecahkan oleh siswa SMP usia 14-15 tahun. Dari sebanyak 34 responden dalam penelitian ini, soal pertama dapat dijawab dengan benar oleh $98 \%$ responden, dengan satu orang menjawab salah dan prinsip kesalahannya adalah pada perhitungan hasil, bukan pada kesalahan pemahaman dan membuat rencana penyelesaian. Sedangkan pada soal kedua dapat dijawab dengan benar dan dengan alasan yang jelas oleh $88 \%$ responden atau 30 orang, 4 orang atau $11 \%$ responden menjawab dengan 
alasan yang kurang benar, dan $1 \%$ responden menjawab salah. Adapun bentuk-bentuk pemahaman siswa terhadap alternatif solusi dalam memecahkan masalah tersebut sebagai berikut.

\section{Soal 2: Aturan Jam Kerja Pegawai}

Kahfi adalah salah satu karyawan di pusat perbelanjaan tersebut. Jika Kahfi menginginkan honor lembur Rp. 300.000 per bulan, berapa tambahan jam kerja yang harus Kahfi capai?

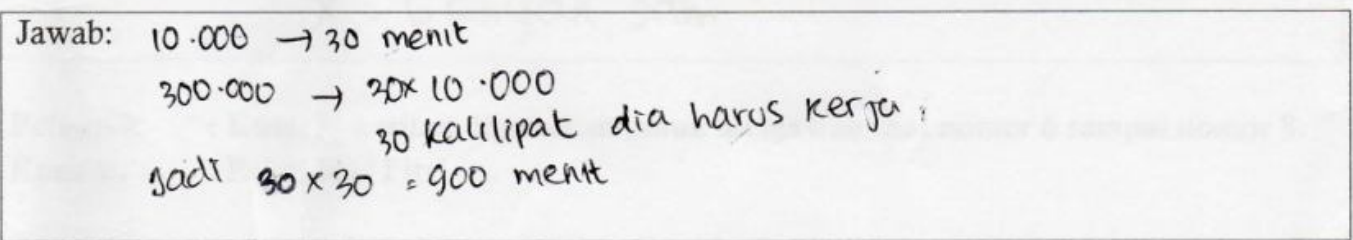

Gambar 2. Alternatif jawaban 1 siswa terhadap soal nomor 1

\section{Soal 2: Aturan Jam Kerja Pegawai}

Kahfi adalah salah satu karyawan di pusat perbelanjaan tersebut. Jika Kahfi menginginkan honor lembur Rp. 300.000 per bulan, berapa tambahan jam kerja yang harus Kahfi capai?

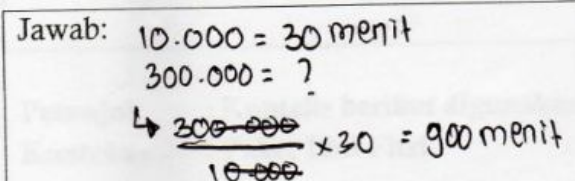

Gambar 3. Alternatif jawaban 2 siswa terhadap soal nomor 1

Soal 2: Aturan Jam Kerja Pegawai

Kahfi adalah salah satu karyawan di pusat perbelanjaan tersebut. Jika Kahfi menginginkan honor lembur Rp. 300.000 per bulan, berapa tambahan jam kerja yang harus Kahfi capai?

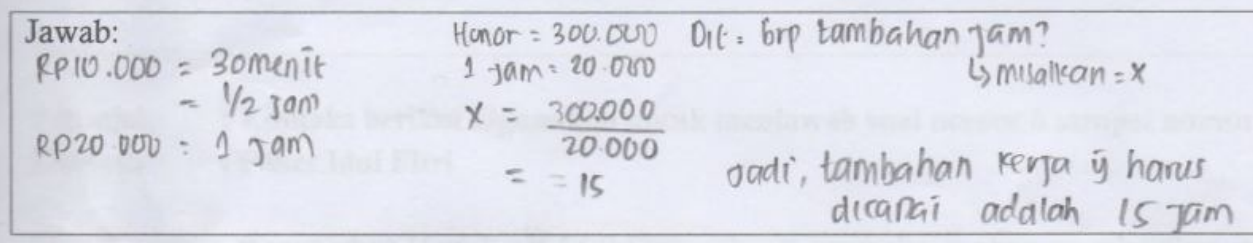

Gambar 4. Alternatif jawaban 3 siswa terhadap soal nomor 1

Soal 2: Aturan Jam Kerja Pegawai

Kahfi adalah salah satu karyawan di pusat perbelanjaan tersebut. Jika Kahfi menginginkan honor lembur Rp. 300.000 per bulan, berapa tambahan jam kerja yang harus Kahfi capai?

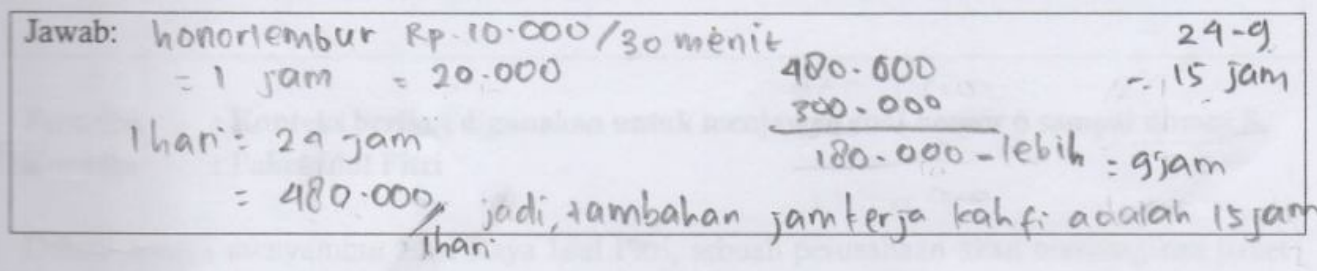

Gambar 5. Alternatif jawaban 4 siswa terhadap soal nomor 1 
Alternatif-alternatif jawaban terhadap soal pertama yaitu menunjukkan bahwa siswa menentukan jumlah jam kerja Kahfi untuk mendapatkan honor lembur dalam satuan menit, satuan jam, satuan menit yang diubah kedalam satuan jam, serta penyelesaian dengan memanfaatkan ide pengubahan dalam 1 jam dan dalam 24 jam. Variasi ke 33 responden tersebut dalam lima alternatif jawaban bernilai benar dengan masing-masing argumentasi. Terdapat $60 \%$ responden menjawab dengan jawaban alhir dalam satuan jam, karena memang soal ini meminta responden menghitung jam lebur dalam satuan jam. Namun terdapat $2 \%$ responden yang menjawab dengan analogi pendekatan dengan satuan per 1 jam dan per 24 jam. Ini cukup menunjukkan bahwa soal yang dirancang cukup memunculkan penalaran soal pada beberapa cara memecahkan masalah yang berbeda-beda.

Soal kedua siswa diminta untuk menentukan honor lembur yang didapat oleh Kahfi jika dalam dua minggu berturut-turut, Kahfi ditentukan jam kerjanya. Secara umum hampir keseluruhan siswa atau sebanyak 31 siswa menjawab bahwa tidak terdapat honor lembur yang diraih Kahfi karena belum terpenuhinya jam kerja maksimal pegawai yang ditentukan oleh pihak perusahaan. Diantara jawaban tersebut, terdapat perbedaan pandangan terhadap pemecahan masalah terkait soal tersebut, dimana dalam perhitungan waktu sesuai dengan informasi yang diberikan soal masingmasing siswa saling berbeda. Adapun variasi bentuk jawaban tersebut dirincikan sebagai berikut.

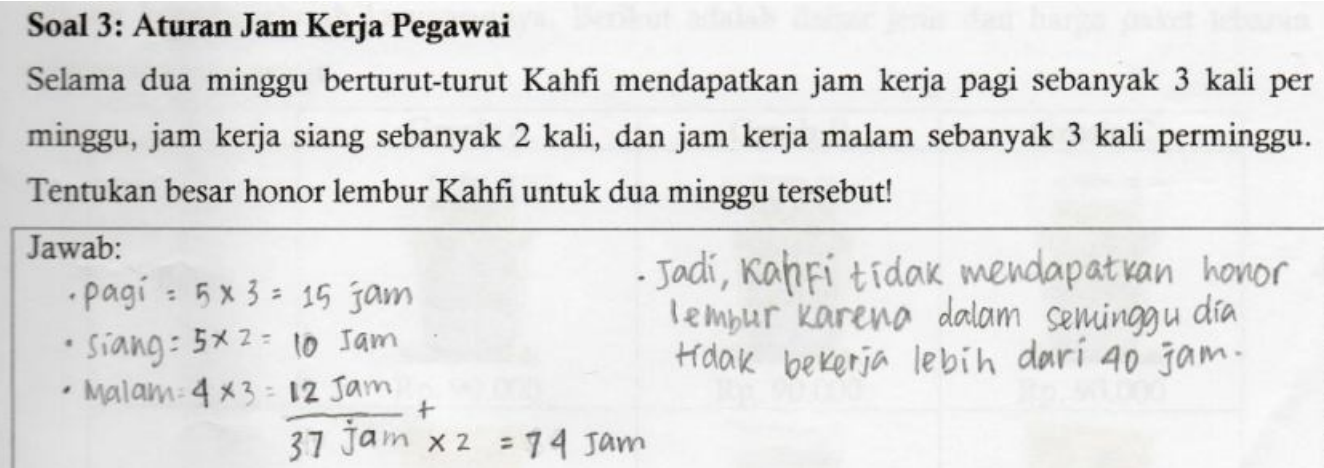

Gambar 6. Alternatif jawaban 1 siswa terhadap soal nomor 2

Diantara 34 responden, terdapat 12 responden atau sekitar 35\% siswa menyelesaikan masalah dengan menggunakan jawaban tipe ini. Ini merupakan jawaban tipe yang benar karena menggunakan informasi yang ada di soal mengenai aturan 
jadwal masuk dan jam istirahat pegawai yang telah ditentukan sesuai dengan informasi yang ada pada soal.

\section{Soal 3: Aturan Jam Kerja Pegawai}

Selama dua minggu berturut-turut Kahfi mendapatkan jam kerja pagi sebanyak 3 kali per minggu, jam kerja siang sebanyak 2 kali, dan jam kerja malam sebanyak 3 kali perminggu.

Tentukan besar honor lembur Kahfi untuk dua minggu tersebut!

\begin{tabular}{|c|c|c|}
\hline $\begin{array}{l}\text { Jawab: } \\
\text { pagi }=3 / \text { minggu } \\
\text { Siang }=2 / \text { minggu } \\
\text { malam }=3 / \text { minggu }\end{array}$ & $\left\{\begin{array}{l}\text { pagi }=5 \mathrm{jam} \times 3=15 \mathrm{jam} \\
\text { siang }=4 \mathrm{jam} \times 2=8 \mathrm{jam} \\
\text { malam }=3 \mathrm{jam} \times 3=\frac{9 \mathrm{jam}}{32 \mathrm{jam}}+\end{array}\right.$ & $\left\{\begin{array}{l}\text { Kahfi }=1 \\
1 \text { minggu }=32 \mathrm{jam} \\
2 \text { minggu }=64 \mathrm{jam} \\
* 1 \text { minggu }=\text { max } 40 \mathrm{jam} \\
\Rightarrow \text { Jadr, Kahfi tidak mandpt- } \\
\text { kan honor lembur. Karena dia }\end{array}\right.$ \\
\hline
\end{tabular}

Gambar 7. Alternatif jawaban 2 siswa terhadap soal nomor 2

Diantara 34 responden, terdapat 3 siswa atau sekitar $8 \%$ siswa yang menjawab dengan jawaban tipe ini. Ini merupakan jawaban yang kurang tepat dalam menggunakan penalaran logis yang terkait dengan kenyataan. Ini ditunjukkan dengan jumlah jam kerja siang dan jam kerja malam yang berkurang satu jam. Dalam persepsi siswa, setiap jam masuk harus melewati masa istirahat terlebih dahulu selama satu jam. Padahal dalam penalaran logis, idealnya masa istirahat baru boleh dimanfaatkan jika pegawai tersebut telah bekerja pada waktu sebelumnya, sedangkan jika pegawai tersebut baru masuk kerja pada suatu jam baik siang maupun malam, pegawai tersebut haruslah langsung bekerja tanpa melewati waktu istirahat terlebih dahulu. Dengan demikian, pada jam kerja siang dan jam kerja malam, aturan jam kerja yang ditentukan menjadi berkurang masing-masing satu jam.

\section{Soal 3: Aturan Jam Kerja Pegawai}

Selama dua minggu berturut-turut Kahfi mendapatkan jam kerja pagi sebanyak 3 kali per minggu, jam kerja siang sebanyak 2 kali, dan jam kerja malam sebanyak 3 kali perminggu.

Tentukan besar honor lembur Kahfi untuk dua minggu tersebut!

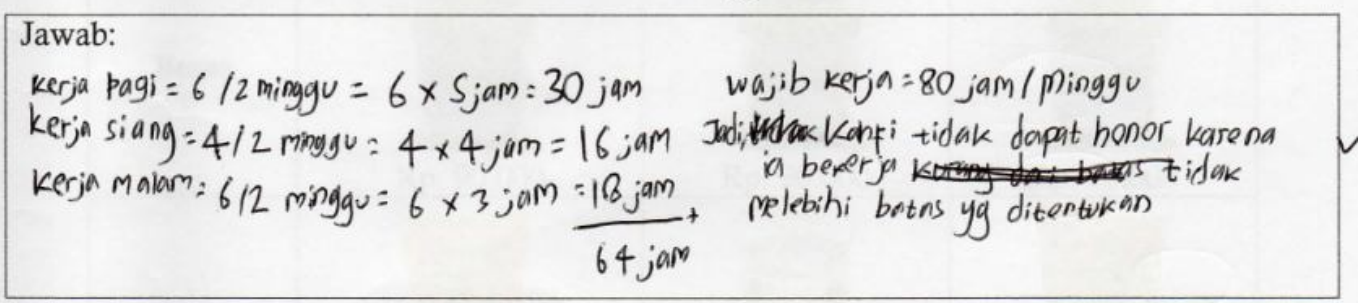

Gambar 8. Alternatif jawaban 3 siswa terhadap soal nomor 2 
Diantara 34 responden, terdapat 17 siswa yang menjawab dengan jawaban tipe ini atau sekitar 50\% siswa. Ini merupakan jawaban yang kurang tepat berdasarkan perhitungan waktu menurut informasi yang diberikan dalam soal. Misalnya jam kerja pagi yang ditentukan yaitu 08.00 - 13.00 adalah sebanyak lima jam, sedangkan jawaban berdasarkan alternatif ketiga ini menunjukkan sebanyak enam jam. Begitu pula pada jam kerja siang dan jam kerja malam, terdapat penambahan masing-masing satu jam. Walaupun jumlah jam menjadi bertambah banyak, namun jawaban tersebut masih belum melewati batas ketercapaian jam kerja maksimal, sehingga jawaban bahwa Kahfi tidak mendapatkan honor lembur dapat muncul. Mengingat ada sekitar setengah dari responden yang menjawab dengan cara ini, maka dapat disimpulkan bahwa terdapat kesalahan persepsi siswa dalam menghitung waktu. Hal ini perlu adanya perbaikan dan perhatian baik bagi guru maupun bagi peneliti.

Ketiga alternatif jawaban tersebut menurut persepsi peneliti tidaklah sepenuhnya benar dan sesuai harapan. Ini disebabkan karena adanya informasi yang tertinggal berdasarkan informasi soal yaitu "setiap pegawai tetap wajib bekerja 8 jam per hari dan maksimal 40 jam per minggu". Mayoritas bahkan hampir seluruh responden menggunakan informasi tentang maksimal jam kerja adalah 40 jam per minggu, namun tidak memanfaatkan informasi bahwa "setiap pegawai tetap wajib bekerja 8 jam per hari”, sehingga dari jam kerja baik pagi, siang, ataupun malam yang mereka perhitungkan belum termasuk informasi jam kerja wajib tersebut. Ini menjadi kelemahan dalam soal karena dianggap pada saat keterangan tentang jam kerja yang dijadwalkan, kurang menekankan pada jam kerja wajib tersebut.

Dari alternatif-alternatif jawaban siswa, tidak ada jawaban yang menunjukkan adanya koefisien, variabel, maupun konstanta yang muncul dalam pembuatan model yang merujuk pada informasi pada masalah yang diajukan. Ini menunjukkan bahwa siswa tidak sadar sedang belajar persamaan linier karena mereka sedang membuat bahasa menurut model matematika yang mereka pahami sendiri. Ini menandakan bahwa siswa berusaha membuat model matematika sendiri dengan menggunakan bahasa yang mereka pahami. Padahal responden dalam penelitian ini adalah siswa usia 14-15 tahun yaitu siswa kelas VII SMP, di mana siswa tersebut telah mempelajari masalah persamaan linier satu dan dua variabel. Namun tidak ada yang menjadikan hal tersebut sebagai model dalam penafsiran informasi yang mereka ambil dari soal. 
Namun hal ini dianggap cukup memberikan respon yang dapat dilanjutkan penelusuran pemahamannya. Ini diketahui berdasarkan hasil refleksi yang didapat. Setelah diberikan permasalahan tersebut, selanjutnya peneliti meminta refleksi diri dari siswa terhadap soal yang telah mereka kerjakan. Berbagai macam tanggapan siswa terhadap perasaan dan pengalaman mereka terhadap soal tersebut diklasifikasikan sebagai berikut.

Tabel 2. Persentase Responsiswa terhadap Pengalaman Pemecahaman Masalah PISA

\begin{tabular}{cccccc}
\hline $\begin{array}{l}\text { Respon Siswa } \\
\text { terhadap Soal }\end{array}$ & Sangat Sulit & Sulit & Cukup Sulit & Biasa Saja & Tidak Sulit \\
\cline { 2 - 6 } & $53 \%$ & $18 \%$ & $24 \%$ & $5 \%$ & $0 \%$ \\
\hline
\end{tabular}

Diantara persentase respon siswa terhadap soal tersebut, terdapat komentarkomentar siswa terhadap pengalamannya ketika memecahkan masalah tersebut. Adapun komentar-komentarnya sebagai berikut.

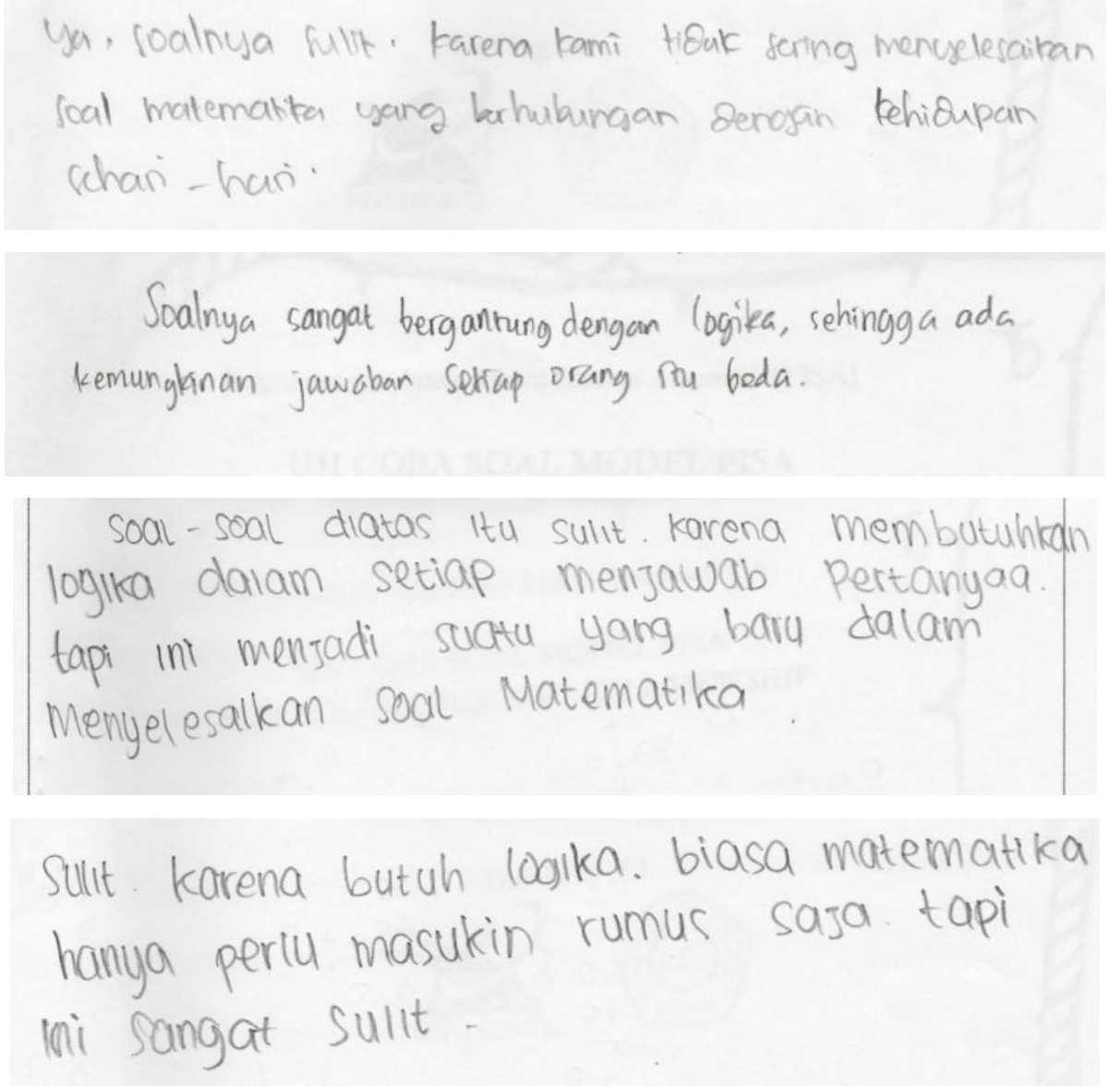

Gambar 7. Komentar siswa terhadap pengalaman memecahkan masalah PISA

Komentar siswa terhadap pengalamannya dalam menyelesaikan soal memang cukup beragam, namun ini menjadi referensi bagi peneliti lainnya. Adapun komentar 
siswa terdiri dari; (1) soal cukup mengasah penalaran (siswa menggunakan istilah "logika") sehingga terkesan berbeli-belit, (2) soal cukup menantang, namun menyenangkan jika berhasil menemukan penyelesaiannya, (3) biasanya soal matematika hanya perlu mensubstitusikan rumus ke dalamnya untuk mendapatkan jawaban yang pasti, (4) soal memungkinkan munculnya jawaban yang berbeda-beda dari masingmasing siswa, (5) soal memuat masalah yang terkait dengan kehidupan sehari-hari, karena tidak terbiasa, jadi siswa merasa sulit memecahkannya.

Berdasarkan komentar-komentar tersebut diketahui bahwa dalam proses belajar mengajar masih minim dalam penggunaan masalah baik sebagai pengantar pembelajaran, membangun konsep, dan memecahkan masalah-masalah yang terkait dengan kehidupan sehari-hari. Pada pada komentar yang lainnya menunjukkan bahwa siswa membutuhkan tantangan dalam belajar matematika, dan hal ini terbukti dengan adanya kepuasan siswa dalam belajar matematika apabila berhasil memecahkan masalah dengan menggunakan konsep pribadi yang mereka bangun. Siswa sendiri menyadari bahwa adanya kemungkinan jawaban yang berbeda-beda diantara siswa, dan siswa cukup demokratis menerima perbedaan jawaban dari teman-temannya. Di sinilah kesempatan bagi pengelola proses pembelajaran dan peneliti untuk merancang intervensi positif dalam pembelajaran yang dapat mendukung terciptanya suasana pembelajarn yang kondusif.

\section{SIMPULAN DAN SARAN}

Penelitian ini telah mengembangkan dan mengujicobakan soal setara PISA pada konten change and relationship, fokus pada persamaan linier, dan konteks pekerjaan. Soal yang dikembangkan merupakan soal pada low order thinking level dengan kriteria yang sesuai. Namun level rendah ini tidak membuat siswa juga mudah dalam menyelesaikannya. Masih banyak terdapat siswa yang kesulitan memecahkan setara PISA ini. Kesulitan siswa terdapat pada ketidakbiasaanya proses belajar mengajar yang melibatkan masalah sehari-hari dalam membangun konsep persamaan linier. Siswa berasumsi bahwa memecahkan masalah matematika erat kaitannya dengan memanipulasi rumus-rumus matematika ke dalam informasi soal yang diberikan. Dengan diberikannya soal ini kepada siswa, siswa mencoba menyelesaikannya dengan membangun konsep pribadinya dan hampir tidak menggunakan rumus matematika 
melaikan menggunakan penalaran yang miliki. Siswa menyadari bahwa soal tersebut cukup sulit dan memungkinkan munculnya model pemecahan masalah yang berbedabeda, dan siswa meyakini bahwa perbedaan jawaban tersebut bukan untuk menentukan kebenaran maupun kesalahan selama mereka memiliki argumentasi yang kuat. Tidak sedikit siswa yang merasa lega apabila berhasil memecahkan masalah ini. Ini menunjukkan bahwa sebenarnya siswa membutuhkan tantangan-tantangan dalam belajar matematika lebih dari kemampuan memanipulasi rumus-rumus.

Sebagai pendidik, peneliti, pemerhati dunia penelitian, hendaknya ini menjadi referensi yang dapat membantu dalam mengembangkan proses belajar mengajar di kelas. Penelitian-penelitian telah membuktikan bahwa belajar matematika tanpa mengaitkannya dengan kejadian nyata atau kehidupan sehari-hari hanya akan menjadi ilmu yang dipahami hanya sebatas rumus-rumus terbatas. Padahal siswa telah menunjukkan bahwa kebutuhannya pada tantangan dan keingintahuan yang tinggi untuk memanfaatkan matematika sebagai ilmu pengetahuan yang dapat memecahkan masalah sehari-hari. Untuk itu perlu adanya dukungan dari banyak pihan untuk merangkul semangat tersebut menjadi suatu karakter dan pembiasaan dalam belajar matematika. Dengan demikian kemampuan matematika Indonesia secara nasional dapat meningkat dan dapat sebanding dan bersaing dengan kemampuan di tingkat internasional.

\section{DAFTAR PUSTAKA}

Arikunto, Suharsimi. 2009. Prosedur Penelitian Suatu Pendekatan Praktik. Jakarta: Rineka Cipta.

Johar, Rahmah. 2012. Domain Soal PISA untuk Literasi Matematika. Jurnal Peluang. Vol 1 No. 1 Oktober 2012. ISSN: 2302-5158.

OECD. 2009a. Learning Mathematics for Life: a View Perspective from PISA. Jurnal

OECD. 2009b. Take the Test Sample Questions from OECD's PISA Assessments. Jurnal.

OECD. 2013a. PISA 2012 Assessment and Analytical Framework.OECD Publishing.

OECD. 2013b. Programme for International Student Assessment. PISA 2012 Result in Focus. Jurnal 
Sari, Intan Kemala. 2016. The Students' Learning Trajectory of Transformation Geometry. International Conference on Mathematics, Science, and Education. Unnes, Semarang

Sudjadi, 2003. Metodologi Penelitian Pendidikan. Jakarta: Rineka Cipta.

Tessmer, Martin. 1993. Planning and Conducting - Formative Evaluations. London, Philadelphia: Kogan Page.

Tjalla, Awaluddin. 2009. Potret Mutu Pendidikan Indonesia Ditinjau dari Hasil-hasil Studi Internasional. Jakarta: FIP Universitas Negeri Jakarta.

Wardhani, Sri. 2011. Program Bermutu Better Education trough Reformed Management and Universal Teacher Upgrading. Yogjakarta: Kementrian Pendidikan Nasional Badan Pengembangan Sumber Daya Manusia Pendidikan Penjaminan Mutu Pendidikan. 